\title{
Efikasi politik dan jenjang partisipasi politik pemilih pemula
}

\author{
Kunto Adi Wibowo ${ }^{1}$, Detta Rahmawan ${ }^{2}$, Azman Hamdika Syafaat ${ }^{3}$ \\ ${ }^{1,2,3}$ Universitas Padjadjaran, Bandung, Indonesia
}

\begin{abstract}
ABSTRAK
Partisipasi politik pemilih pemula secara teoritis memiliki beragam bentuk dan saluran. Sementara di Indonesia, dalam hal ini Komisi Pemilihan Umum Indonesia memiliki fokus pada peningkatan partisipasi politik electoral terutama pada kelompok pemilih pemula. Terkait dengan hal tersebut, maka penelitian ini melakukan studi mengenai partisipasi politik dari Civic Voluntarism Model (CVM) terutama aspek efikasi politik sebagai prediktor utama partisipasi politik pemilih pemula. Selain itu, penelitian ini juga melakukan penyelidikan terkait jenjang partisipasi dari perspektif risiko, sumber daya, dan fokus intervensi institusi politik di Indonesia. Pengumpulan data dilakukan secara tatap muka dan daring kepada 406 mahasiswa Universitas Padjadjaran dari tanggal 28 Mei 2019 sampai dengan 16 Juli 2019. Setelah pengumpulan data selesai dilakukan, selanjutnya penelitian ini menggunakan analisis regresi mediasi dengan efikasi politik sebagai prediktor dan partisipasi politik secara daring, luring, serta memilih pada pemilu 2019 secara berurutan merupakan mediator dan efek. Hasil penelitian mendemonstrasikan bahwa efikasi politik tidak memprediksi partisipasi memilih secara langsung. Efikasi politik memprediksi partisipasi politik daring, dan partisipasi politik daring selanjutnya memprediksi partisipasi politik luring, namun partisipasi politik luring tidak memprediksi partisipasi memilih pada pemilu 2019. Selanjutnya, isu praktis dan akademis terkait partisipasi politik dan konsolidasi demokrasi didiskusikan dalam bagian akhir dari artikel ini.
\end{abstract}

Kata-kata Kunci: Partisipasi politik daring; partisipasi politik luring; partisipasi politik memilih; efikasi politik; pemilih pemula

\section{Political efficacy and political participation continuum of first-time voters}

\section{ABSTRACT}

Theoretically, the political participation of first-time voters is diverse in terms of forms and platforms. However, in Indonesia, Indonesia's General Election Committee has been focused on socialization to improve electoral political participation or voter turnout, particularly toward firsttime voters. This study then examined political participation from the lens of the Civic Voluntarism Model (CVM), specifically from the political efficacy as the main predictor of first-time voters' political participation. Furthermore, this research also scrutinized the political participation continuum from the perspectives of risks, resources, and focus of intervention from Indonesia's political institutions. Data were collected using face-to-face and online questionnaires to 406 students of Universitas Padjadjaran from May 28th to July 16th, 2019. Afterward, this research employed mediation regression analysis with political efficacy as predictors and online, offline, voting political participation as mediators and effect, respectively. Result demonstrated that political efficacy did not predict voting. However, our findings also show that political efficacy predicted online political participation, and in turn, online political participation predicted offline political participation; nevertheless, offline political participation did not predict voting in the 2019 general election. Finally, practical and academic recommendations related to political participation and democratic consolidation are further discussed in the last section of the article.

Keywords: Online political participation; offline political participation; voting; political efficacy; first-time voters

Korespondensi: Kunto Adi Wibowo, Ph.D. Universitas Padjadjaran, Jln Raya Bandung Sumedang, KM 21 Jatinangor.Email: kunto.a.wibowo@unpad.ac.id 


\section{PENDAHULUAN}

Pemilihan umum (Pemilu) serentak 2019 berhasil meningkatkan angka partisipasi pemilih hampir $10 \%$ dari $70 \%$ pada Pemilihan presiden (Pilpres) 2014 dan 75\% di Pemilihan anggota legislatif(Pileg) 2014 menjadi 81\% pada pemilu 2019 (Farisa, 2019). Komisi Pemilihan Umum Indonesia (KPU) menyebut naiknya angka partisipasi pemilih pada pemilu 2019 sebagai bukti pada tingkat kepercayaan masyarakat terhadap KPU. Sedangkan salah seorang anggota KPU di daerah menyatakan bahwa tingginya partisipasi politik pada pemilu 2019 disebabkan beberapa faktor, antara lain, pemilu serentak 2019 yang menggabungkan Pemilihan Presiden dan Pemilihan Legislatif sehingga kegairahan menjadi berlipat dua, keberhasilan sosialisasi KPU kepada stakeholder terutama pemilih pemula, solidaritas masyarakat pedesaan yang tinggi, politik uang, dan kecurangan baik sengaja maupun tidak sengaja pada Daftar Pemilih Tetap (DPT) (Ro'is, 2019).

Pasca reformasi, analis politik Indonesia memberikan perhatian besar terhadap voting sebagai bentuk partisipasi politik (Wardhani, 2018; Nurhadi \& Sunarso, 2018; Yustiningrum, Emilia, Ichwanuddin, \& Wawan, 2015). Hal yang sama juga mengisi wacana di media arus utama, di mana parameter partisipasi politik diukur berdasarkan persentase warga yang turut serta dalam kegiatan pemilu atau voter turnout (Wagunu, Kustiasih, Pattisina, Rinaldi, \& Yossihara, 2019). Padahal dalam literatur dan penelitian tentang partisipasi politik di dunia, partisipasi politik melampaui partisipasi electoral dalam bentuk voting atau memilih dalam pemilu dan meliputi definisi yang lebih luas termasuk aktivitas demonstrasi, boikot, menghubungi pejabat publik, dan menjadi relawan di komunitas mereka (Boulianne, 2018; de Zuniga, Jung, \& Valenzuela, 2012). Definisi partisipasi politik pada esensinya adalah sebuah saluran komunikasi dimana warga negara dapat mengkomunikasikan kebutuhan, aspirasi, preferensi, dan kekhawatiran mereka kepada para pengambil keputusan politik (Verba, Schlozman, \& Brady, 1995). Komunikasi ini tidak terbatas pada ritual 5 tahunan dalam bentuk pemilu. Namun lebih luas lagi partisipasi politik melingkupi aktivitas komunikasi dalam bentuk yang informal dan bahkan deviant. Lebih lanjut partisipasi politik merupakan aktivitas warga negara yang inheren di dalam demokrasi.

Pada perspektif partisipasi politik yang mengandalkan analisis persentase partisipasi pemilih (voter turnout) sering ditemukan simpulan generasi muda Indonesia merupakan generasi yang cenderung apolitis. Terutama atas apa yang terjadi pada pemilu 2014, di mana angka golput Indonesia mengalami peningkatan yang signifikan, dan persentase milenial berada di angka 24,89\% (Djuyandi, 2014). Hal yang serupa juga terjadi di Amerika di mana majalah terkemuka Economist mengatakan bahwa generasi muda terkena 'wabah' apatisme politik dan karenanya tidak memiliki pendapat politik yang kuat (The Economist, 2014).

Walaupun klaim tersebut kemudian dapat dipertanyakan lebih jauh terutama pada realitas politik kontemporer, di mana generasi muda beberapa tahun ini menjadi motor metoo movement maupun climate strikes yang kemudian mempengaruhi aktivisme politik secara global. Di Indonesia terjadi demonstrasi besar-besaran dan gelombang protes terhadap politik perundang-undangan oleh parlemen dan pemerintah pada September 2019. Demonstrasi yang dimotori oleh mahasiswa, yang notabene kerap dicap sebagai mereka yang apolitis terjadi berurutan di kota-kota besar di Indonesia yaitu Yogyakarta, Malang, Semarang, Balikpapan, Jakarta, Samarinda pada, Banda Aceh, Medan, Padang, Palembang, Pekanbaru, Banjarmasin, Makassar, Riau, Lampung, Jember, Bandung, Tasikmalaya, Surabaya dan Kendari (Saputri, 2019). Demonstrasi tersebut menunjukkan bahwa, mahasiswa yang mayoritas memiliki usia muda memiliki perhatian dan mencoba berpartisipasi dalam wacana politik, namun dengan jalan yang berbeda. Mereka juga terbukti membawa aspirasi publik, dan menjadi penguat suara masyarakat (KedaiKOPI, 2019).

Institusi demokrasi di Indonesia seperti KPU sebagai penyelenggara pemilu selama ini menitikberatkan pada angka partisipasi pemilih pemula. Apalagi ukuran partisipasi politik dari negara-negara Barat (western), berpendidikan tinggi (educated), industrialisasi (industrialized), kaya (rich), dan demokratis (democratic) yang disingkat menjadi WEIRD, sangat mungkin tidak sesuai dengan kultur politik negara berkembang dan relatif baru dalam demokratisasi seperti Indonesia. Terlebih beberapa butir pengukuran misalnya melibatkan aktivitas partisipasi politik yang tidak lazim 
di Indonesia seperti mengontak pejabat publik atau anggota legislatif, demonstrasi, dan menyumbang uang pada peserta pemilu (Boulianne, 2018; de Zuniga et al., 2012). Sementara teori tentang partisipasi politik dibangun dengan alat ukur di atas dan diujikan di negara-negara WEIRD. Untuk itu dibutuhkan kajian tentang seberapa sesuai ukuran tersebut digunakan di Indonesia dan dengan demikian mengkaji secara kritis teori-teori partisipasi politik dalam konteks platform partisipasi dan pemilih pemula.

Studi ini berupaya untuk menguji sejauh mana teori partisipasi politik yang fokus pada dimensi psikososial yakni efikasi politik dapat memprediksi partisipasi politik electoral, partisipasi politik daring, serta partisipasi politik luring. Studi ini juga berupaya memprediksi pengaruh efikasi politik terhadap partisipasi politik electoral ketika partisipasi politik daring dan luring menjadi mediator dalam model. Studi ini akan menjadikan pemilih pemula dalam pemilu 2019 sebagai populasi dan sampel.

Partisipasi politik warga menjadi saluran di mana warga negara dapat mengkomunikasikan informasi terkait kebutuhan, preferensi dan kekhawatiran mereka kepada para pengambil keputusan politik, warga dapat turut serta memberikan kontribusi politis terhadap pengambilan keputusan politik (Verba et al., 1995).

Partisipasi politik kini telah menjadi konsep yang sangat komprehensif ketimbang unidimensional, seperti ketika ia pada awalnya dibicarakan dan masuk ke dalam khazanah politik. Sifat ambigu dari diskusi tentang partisipasi politik dalam beberapa tahun terakhir berarti bahwa mendapatkan kejelasan tentang kegiatan yang merupakan bentuk partisipasi politik yang demokratis menjadi sangat penting.

Partisipasi politik merupakan hal fundamental dalam proses konsolidasi demokrasi. Namun studi-studi yang ada di Indonesia, terlalu memberikan perhatian besar terhadap voting sebagai bentuk partisipasi politik (Wardhani, 2018; Nurhadi \& Sunarso, 2018; Yustiningrum, Emilia, Ichwanuddin, \& Wawan, 2015). Serupa dengan studi-studi yang dominan di Indonesia tentang partisipasi politik, studi yang tersedia secara global juga lebih banyak terfokus pada partisipasi pada kampanye politik, seperti voting, menghadiri kampanye dan upaya untuk mengajak memilih. Mayoritas studi juga terbatas pada analisis atas situasi partisipasi politik pemilihan umum di dalam satu negara. Padahal, partisipasi politik semestinya mengacu pada semua bentuk keterlibatan di mana warga negara mengekspresikan pendapat politik mereka dan/atau menyampaikan pendapat itu kepada para pembuat keputusan politik (Vissers \& Stolle, 2014). Definisi partisipasi politik yang lebih luas, membuat dimensi publik tidak sekadar dibicarakan dalam lingkup elit politik, namun pada kanvas keterlibatan warga terhadap berbagai dimensi masyarakat sipil.

Terdapat bukti-bukti empiris yang kuat, di mana di akhir 90 dan awal 2000-an bentuk-bentuk tradisional partisipasi politik di ranah parlementer mengalami penurunan di masyarakat Barat (Putnam, 2000; Skocpol, 2003). Para akademisi menjelaskan terjadi perubahan sifat dalam lingkup partisipasi politik. Repertoar partisipasi politik tradisional digantikan oleh bentuk-bentuk baru seperti politik 'gaya hidup', konsumerisme politik, aktivisme Internet (Dalton, 2008; Inglehart \& Welzel, 2005; Schlozman,Verba, \& Brady, 2010; Stolle \& Micheletti, 2013).

Bentuk-bentuk partisipasi politik akan memiliki perbedaan, terutama dalam hal motivasi, sumberdaya serta efek, serta kemampuan dalam hal penggandaannya. Aktivisme politik lain memiliki banyak kelebihan ketimbang sekadar tindak politik prosedural seperti voting. Tindakan kaya informasi seperti melakukan kontak dengan pejabat menjadi mekanisme mediasi yang tepat untuk menyampaikan pesan spesifik dan rinci (Verba et al., 1995).

Perkembangan Internet dan media sosial juga menciptakan alternatif lain bentuk-bentuk partisipasi politik. Internet dan media sosial membuka peluang jenis keterlibatan politik yang secara praktik tidak sama dengan yang terjadi pada partisipasi politik luring: misalnya meluasnya penggunaan humor dalam posting politik - satire, sarkasme, meme; dukungan nyata untuk organisasi sosial / politik, kandidat, dan tujuan sosial / politik tertentu melalui petisi daring; mobilisasi kampanye dengan jangkauan luas yang belum pernah terbayangkan sebelumnya; atau peretasan atau hacking yang dengan motivasi politik (Chadwick, 2006; Raine \& Smith, 2008; Vitak et al., 2011).

Internet telah memfasilitasi pendekatan yang baru terkait partisipasi politik, hal yang 
disebabkan internet memiliki kualitas serta kemampuan reproduksi yang berbeda, termasuk dalam hal ini kemampuan pembuatan (siapapun dapat membuat berita), interaksi dan pertukaran sosial langsung dan luas, dan secara signifikan mengurangi biaya untuk berbagi informasi, pendapat dan untuk memobilisasi melalui jejaring yang lebih luas (Chadwick, 2006; Haynes \& Pitts, 2009)

Partisipasi merupakan konsep kunci yang menjelaskan perbedaan antara Internet 1.0 dan Internet 2.0, termasuk dalam hal ekstensifikasi hingga penemuan media sosial. Media sosial mengeskalasi partisipasi pada titik yang tidak terbayangkan sebelumnya (Effing, Hillegersberg, \& Huibers, 2011). Partisipasi dalam definisi Xie, Bo dan Jaeger (2008) dalam lingkup politik mendefinisikan partisipasi politik sebagai "perilaku yang bertujuan membentuk kebijakan pemerintah, baik dengan mempengaruhi pemilihan personil pemerintah atau dengan mempengaruhi pilihan mereka". Dengan munculnya Media Sosial, politisi dan pemerintah dapat menciptakan peluang untuk partisipasi politik: memungkinkan, melibatkan dan memberdayakan pengikut untuk berbagai manfaat (Effing et al., 2011).

Walaupun pada akhirnya terdapat sekat algoritme serta aktor-aktor politik dominan di dalam internet dan media sosial, namun studi yang telah dilakukan menunjukkan bahwa terdapat korelasi positif antara penggunaan media daring dengan partisipasi dalam masyarakat sipil dan politik (Boulianne, 2009; Boulianne, 2015; Chae, Lee, \& Kim, 2018; Skoric, Zhu, Goh, \& Pang, 2016)

Terdapat beberapa studi yang menunjukkan bahwa partisipasi politik daring berpengaruh terhadap ketertarikan terhadap isu/topik/dimensi politik penggunanya (Strandberg, 2013; Jessica Vitak \& Ellison, 2013; J Vitak et al., 2011; Zhang, Johnson, Seltzer, \& Bichard, 2010) di mana keinginan untuk datang dan melakukan voting hanyalah salah satu wujudnya.

Pada hari ini hampir tidak ada aktivisme luring terutama yang berada di lingkup urban dan menargetkan dimensi politik luas, yang tidak berhutang terhadap aktivisme dan partisipasi politik daring. Dunia daring menjadi fondasi dan tempat di mana wacana publik beresonansi. Penguatan terhadap satu isu terjadi di media online, yang kemudian ekspresinya juga bisa menyublim melalui gerakan-gerakan luring seperti demonstrasi, boikot, maupun partisipasi politik lain (Vissers \& Stolle, 2014).

Bagi generasi muda, kanal seperti media digital memberikan implikasi berbeda terhadap bentuk-bentuk partisipasi politiknya, apabila dibandingkan dengan generasi pada rentang usia lain (Shah, Kwak, \& Holbert, 2001; Shah, McLeod, \& Yoon, 2001). Kehidupan kaum muda dibentuk oleh penggunaan intensif teknologi digital baru mereka dengan cara yang, beberapa berpendapat, tidak memiliki preseden dan dengan perubahan dramatis dalam sikap dan perilaku mereka. Berada pada tahap kehidupan yang kritis di mana tingkat minat dan keterlibatan politik mereka dapat ditempa, temuan dari studi pemuda dapat "menunjukkan" bagaimana teknologi akan membentuk keterlibatan masa depan mereka, serta usia lainnya (Jenkins, Ito, \& Boyd, 2016). Pada kasus Indonesia misalnya, demonstrasi yang terjadi pada September 2019, memancing sentimen negatif terutama oleh mereka yang berada pada rentang usia di atas mereka yang berdemonstrasi. Gap ekspresi politik antara anak-anak muda dengan generasi usia di atasnya termanifestasi dalam berbagai perdebatan politik di media sosial.

Verba membangun Civic Voluntarism Model (CVM) - model partisipasi masyarakat sipil yang merangkum berbagai teori sosial psikologis untuk menjelaskan mengapa seseorang berpartisipasi dalam kegiatan politik (Verba, 1995). Temuan Verba menjelaskan bahwa terdapat tiga alasan seseorang berpartisipasi dalam kegiatan politik: 1) mereka dapat; 2) mereka ingin; atau 3) seseorang meminta mereka untuk turut ambil bagian. Tiga alasan ini dapat dinyatakan sebagai tiga faktor utama yang mempengaruhi partisipasi, yaitu: 1) sumber daya pribadi untuk berpartisipasi; 2) sikap politik yang memotivasi partisipasi; dan 3) kelompok masyarakat yang memotivasi partisipasi (Dalton, 2008).

Dalton menjelaskan bahwa politik dan karakteristik warga untuk ambil bagian dalam aktivitas politik telah berubah selama bertahuntahun. Hal yang membuat terjadinya proses transformasi praktik politik dan demokratisasi di mana warga negara berpartisipasi. Studi Dalton menggabungkan tujuh variabel untuk mewakili tiga faktor, yaitu: 1) pendidikan, 2) usia, 3) jenis kelamin, 4) efikasi politik, 5) sikap politik kiri/kanan, 6) keterikatan partai politik, dan 
7) keanggotaan dalam serikat atau kelompok bisnis. Data yang terkumpul kemudian dianalisis secara statistik untuk mengidentifikasi variabel mana yang merupakan prediktor partisipasi politik (Dalton, 2008).

Penelitian ini fokus kepada kelompok pemilih pemula yang diasumsikan memiliki tingkat partisipasi politik yang terendah di antara kelompok usia lainnya sehingga KPU memilih kelompok usia muda ini sebagai target kegiatan sosialisasi mereka. Usia pemilih pemula berada pada kisaran 17-22 tahun karena pemilu di Indonesia diadakan setiap 5 tahun sekali.

Selain usia, penelitian ini juga fokus pada mahasiswa sebagai pemilih pemula. Membuat dua variabel utama partisipasi dalam posisi konstan dan tidak bervariasi akan memudahkan dalam memeriksa faktor lain yang lebih penting, yang penelitian terdahulu secara konsisten memprediksi partisipasi pemilih terutama pemilih pemula, yakni efikasi politik (Moeller, de Vreese, Esser, \& Kunz, 2014).

Ekonomi juga merupakan salah satu prediktor kuat terkait partisipasi pemilih. Studi menunjukkan mereka yang memiliki pekerjaan bergaji tinggi, atau mereka yang datang dari latar belakang sosial ekonomi yang lebih tinggi, lebih berpotensi memiliki pengetahuan terkait pemungutan suara. Mereka juga lebih terstimulasi secara politis dibandingkan rekan sejawat mereka yang tidak memiliki privilege yang sama dengan mereka (Tenn, 2007)

Selain variabel usia, pendidikan dan ekonomi, terdapat variabel lain yang dianggap signifikan mempengaruhi tingkat partisipasi politik. Gender, sepanjang sejarah partisipasi politik kesenjangan gender adalah hal yang terus didiskusikan dan terus ada dalam aras politik kita. Hal ini terjadi karena pembagian peran di dalam masyarakat dan kultur patriarki, di mana perempuan mendapatkan peran domestik. Namun penelitian-penelitian yang ada, menunjukkan bahwa kesenjangan gender dalam jumlah pemilih secara bertahap menghilang (Inglehart \& Norris, 2004).

Efikasi politik dalam studi politik telah cukup lama dianggap sebagai salah satu dari beberapa anteseden terhadap partisipasi dalam politik institusional (Verba et al., 1995). Efikasi politik dapat diartikan sebagai persepsi yang dimiliki seseorang tentang dirinya dan kemampuan untuk mempengaruhi politik pada situasi tertentu (Ramdhani, 2008).
Terdapat dua jenis efikasi politik: efikasi eksternal dan internal. Efikasi internal yaitu kepercayaan bahwa seseorang dapat memahami politik dan karenanya berpartisipasi dalam politik dan efikasi eksternal bahwa pemerintah akan menanggapi tuntutan seseorang. Perasaan mampubertindakefektiftelah didokumentasikan secara luas oleh penelitian sebelumnya sebagai salah satu variabel psikologis utama yang mampu menjelaskan partisipasi warga negara (Niemi, Craig, \& Mattei, 1991). Banyak yang lebih percaya pada sistem politik dan pada orang lain akan lebih cenderung memiliki pandangan positif tentang cara kerja proses pemilihan (Bélanger \& Nadeau, 2005). Demikian juga kepuasan dengan demokrasi dihipotesiskan untuk meningkatkan jumlah pemilih.

Namun, sebuah kajian meta-analisis tidak mengkonfirmasi hipotesis bahwa pandangan positif tentang cara kerja politik/demokrasi atau efikasi politik eksternal dapat memprediksi partisipasi politik seseorang. Hal ini disebabkan sebagian besar penelitian menemukan variabel terkait efikasi politik tidak signifikan secara statistik (Smets \& van Ham, 2013). Pada akhirnya diperlukan pengukuran lebih jauh terkait sejauh apa efikasi politik berpengaruh terhadap partisipasi politik daring dan partisipasi politik luring, juga kemudian dengan intensi melakukan votes.

Berikut adalah hipotesis yang diuji dalam penelitian ini

H1: Efikasi politik memprediksi partisipasi politik pemilih pemula dalam memilih pada pemilu 2019

H2: Efikasi politik memprediksi partisipasi politik daring pemilih pemula dalam pemilu 2019

H3: Efikasi politik memprediksi partisipasi luring pemilih pemula dalam pemilu 2019 melalui partisipasi daring mereka

H4: Efikasi politik memprediksi partisipasi pemilih pemula dalam memilih pada pemilu 2019 melalui partisipasi daring dan partisipasi luring mereka secara berurutan

\section{METODE PENELITIAN}

Populasi dalam penelitian ini adalah Mahasiswa aktif tingkat sarjana (S1) Universitas Padjadjaran yang menjadi pemilih pemula dalam pemilu 2019 yakni dari angkatan 2016 sampai dengan angkatan 2018 merupakan 
populasi penelitian ini. Data dari Direktorat sistem perencanaan Universitas Padjadjaran menyebutkan terdapat 17.406 mahasiswa aktif dari angkatan 2016-2018 yang tersebar di 16 fakultas yang menjadi ukuran populasi dalam penelitian. Universitas Padjadjaran merupakan institusi pendidikan tinggi terbesar di Jawa Barat yang merupakan provinsi dengan jumlah pemilih terbesar di Indonesia. Lebih lanjut pemilih pemula merupakan target sosialisasi KPU menjelang pemilu 2019 untuk mendorong partisipasi politik electoral dalam bentuk memilih kandidat di bilik suara.

Ukuran sampel dalam penelitian ini dikalkulasikan dengan formula Yamane dimana ukuran sampel diperoleh dari ukuran populasi dibagi dengan ukuran populasi dikalikan kesalahan pencuplikan ditambah bilangan satu (Yamane, 1973).

$$
n=\frac{N}{N d^{2}+1}
$$

Dimana $N$ adalah ukuran populasi dan $d$ adalah tingkat kesalahan pencuplikan, sedangkan $\mathrm{n}$ adalah ukuran sampel. Dengan tingkat kesalahan pencuplikan ditetapkan sebesar 5\% dengan tingkat kepercayaan 95\%, maka ukuran sampel yang dibutuhkan adalah.

$$
\frac{17406}{17406 \times(0.05)^{2}+1}=391,01
$$

Untuk mengantisipasi kuesioner yang tidak kembali atau nonresponse dan kesalahan pengisian kuesioner oleh responden, maka ukuran sampel dibulatkan menuju angka puluhan ke atas terdekat, menjadi 400 responden.

Penelitian ini menggunakan teknik samping klaster acak dengan langkah-langkah sebagai berikut: (1) Dari 16 fakultas di Universitas Padjadjaran dibagi menjadi dua klaster besar yakni fakultas rumpun ilmu pasti alam dan fakultas rumpun ilmu sosial humaniora. Dua klaster ini dihitung proporsinya yakni 2 ilmu pasti dibanding 1 sosial humaniora. (2) Memilih secara acak dengan mengundi kertas yang bertuliskan nama fakultas dan terpilih Fakultas Teknologi Industri Pertanian dan Fakultas Psikologi untuk rumpun ilmu pasti alam serta Fakultas Ilmu Komunikasi untuk rumpun ilmu sosial humaniora. (3) Mengundi secara acak program studi, angkatan, dan kelas di masingmasing fakultas sehingga dengan asumsi setiap fakultas mendapatkan proporsi $1 / 3$ dari ukuran sampel secara keseluruhan atau \pm 134 mahasiswa. (4) Menyebarkan kuesioner dengan cara mendatangi kelas dan meminta waktu kepada dosen mata kuliah setelah perkuliahan atau menghubungi ketua kelas terpilih dan meminta untuk menyebarkan tautan kuesioner online kepada seluruh mahasiswa di kelas tersebut.

Pengumpulan data dilakukan dari tanggal 28 Mei 2019 sampai dengan 16 Juli 2019 atau dimulai berselang 40 hari dari pemungutan suara pemilu 2019 sehingga diharapkan responden belum lupa atas apa yang dilakukan selama masa kampanye dan pemungutan suara pada pemilu 2019. Terdapat 406 kuesioner yang kembali dari 462 mahasiswa yang tercatat di semua kelas yang terpilih melalui metode klaster acak. Dengan demikian response rate untuk penelitian ini adalah $88 \%$ yang diperoleh dari membagi jumlah kuesioner kembali dengan kuesioner yang disebarkan. Menurut Groves dan Peytcheva (2008) semakin tinggi tingkat respons maka semakin rendah bias yang dihasilkan dari nonresponse. Selain itu tingkat respon yang ditoleransi untuk survei pada khalayak umum adalah di atas $60 \%$ sedangkan untuk sekolah atau Universitas diharapkan melampaui angka 80\% (Fincham, 2008; Groves \& Peytcheva, 2008).

Rata-rata usia responden adalah 19,74 tahun $(\mathrm{SD}=0,99)$ dengan median pada 20 tahun. Usia paling muda adalah 17 tahun dan usia paling tua adalah 22 tahun. 70,2\% responden adalah perempuan. Sebaran fakultas responden adalah 138 mahasiswa (34\%) Fakultas Teknologi Industri Pertanian, 134 mahasiswa (33\%) Fakultas Psikologi, dan 134 mahasiswa (33\%) mahasiswa Fakultas Ilmu Komunikasi.

Variabel dependen penelitian ini adalah memilih di bilik suara saat pemilu 2019 atau "mencoblos" yang diukur dengan skala biner (ya/tidak) untuk pertanyaan tentang mencoblos 5 surat suara (Presiden, Dewan Perwakilan Rakyat, Dewan Perwakilan Daerah, Dewan Perwakilan Rakyat Daerah Provinsi, dan Dewan Perwakilan Rakyat Kabupaten/Kota). Index partisipasi politik memberikan suara pada pemilu 2019 dibangun dengan menjumlahkan skor dari 5 pertanyaan biner di atas. Rata-rata 
partisipasi politik mencoblos responden adalah $3,85(\mathrm{SD}=1,90)$ dan hasil uji Cronbach's $\alpha=$ 0,95 .

Variabel dependen kedua adalah partisipasi politik luring yang alat ukurnya diadopsi dari penelitian de Zuniga, Jung, dan Valenzuela (2012). Terdapat 6 butir pertanyaan dengan menggunakan skala semantic differential 7 poin $(1=$ tidak pernah $-7=$ selalu $)$ tentang frekuensi menjadi relawan dalam kampanye luring, menyumbangkan uang kepada peserta pemilu secara luring, menggunakan atribut peserta pemilu di luring, menyampaikan aspirasi kepada peserta pemilu secara luring, mengikuti kampanye massal dan demonstrasi, serta menandatangani petisi luring sepanjang masa kampanye pemilu 2019. Rerata skor responden adalah $1,36(\mathrm{SD}=0,66)$ dengan hasil uji Cronbach's $\alpha=0,81$.

Variabel dependen ketiga adalah partisipasi politik daring yang mengadopsi alat ukur dari de Zuniga, Jung, dan Valenzuela (2012). Terdapat 6 butir pertanyaan dengan skala semantic differential 7 poin $(1=$ tidak pernah $-7=$ selalu). Responden ditanyakan tentang frekuensi menjadi relawan dalam kampanye daring, menyumbangkan uang kepada peserta pemilu secara daring, menggunakan atribut peserta pemilu di konteks daring, menyampaikan aspirasi kepada peserta pemilu secara daring, mengikuti kampanye secara daring, serta menandatangani petisi daring sepanjang masa kampanye pemilu 2019. Ratarata skor responden untuk partisipasi daring adalah 1,65 $(\mathrm{SD}=0,84)$, hasil uji Cronbach's $\alpha=0,78$.

Variabel independen utama dalam penelitian ini adalah efikasi politik pemilih pemula yang diadopsi dari Morell (2005). Terdapat dua dimensi efikasi politik yakni efikasi internal dan efikasi eksternal. Efikasi internal diukur dengan 4 butir pertanyaan tentang persepsi kemampuan berpartisipasi politik secara aktif, mendapatkan informasi dengan baik, pemahaman isu politik yang baik, dan menjadi calon pejabat publik yang baik. Sedangkan efikasi eksternal diukur dengan 3 butir pertanyaan yang membahas tentang kemampuan memahami politik dan dinamikanya, persepsi pemerintah melayani rakyat, dan pemerintah berlaku responsif pada aspirasi rakyat. Semua pertanyaan menggunakan skala semantic differential 7 poin $(1=$ sangat tidak setuju $-7=$ sangat setuju). Tingkat efikasi politik responden relatif sedang $(\mathrm{M}=3,53$; SD $=1,19)$. Hasil uji reliabilitas menunjukkan hasil yang sangat handal (Cronbach's $\alpha=0,86$ ).

Pengetahuan politik di dalam penelitian ini berperan sebagai variabel kontrol atau covariat. Terdapat 5 butir pertanyaan untuk mengukur pengetahuan politik sesuai dengan rekomendasi dari Delli Carpini dan Keeter (1993). Karena konteks penelitian adalah pemilu atau partisipasi electoral, maka pengetahuan politik yang diukur juga terkait dengan pengetahuan politik electoral yakni pemenang pemilu 2014, nama calon wakil presiden pasangan calon presiden (capres) dan calon wakil presiden (cawapres) 01, nama ketua Partai Persatuan Pembangunan yang ditangkap Komisi Pemberantasan Korupsi, program pasangan 01, dan program pasangan 02. Pada setiap pertanyaan disediakan 5 pilihan jawaban dengan satu pilihan yang benar, tiga pilihan lainnya salah, dan satu pilihan "tidak tahu". Pilihan jawaban benar mendapatkan skor 1 sedangkan jawaban selain jawaban benar bernilai 0 . Rerata nilai pengetahuan politik responden adalah $0,66(\mathrm{SD}=0,27)$ dengan 94 mahasiswa $(23,2 \%)$ menjawab semua pertanyaan benar.

Untuk mengukur status sosial ekonomi, penelitian ini menggunakan tingkatan kelompok Uang Kuliah Tunggal atau besaran iuran pendidikan yang harus dibayarkan oleh mahasiswa setiap semesternya. Terdapat 5 kelompok besaran UKT dan satu kelompok Bidik Misi. Kelompok UKT tersebut dikoding dengan kelompok Bidik Misi diberi kode 0 dan kelompok UKT 1-5 sesuai dengan besaran iuran pendidikan. Mayoritas $(50,5 \%)$ responden berada pada kelompok 4 dengan iuran pendidikan sebesar 4 sampai dengan 7 juta rupiah setiap semester $(\mathrm{M}=3,54 ; \mathrm{SD}=1,22)$.

Data dianalisis dengan analisis regresi mediasi berganda serial dengan tiga model. Model pertama menganalisis variabel independen dan covariat dalam memprediksi variabel dependen partisipasi daring. Dilanjutkan dengan independen, covariat, dan partisipasi daring memprediksi partisipasi luring. Model terakhir memprediksi partisipasi mencoblos dengan memasukkan semua variabel lainnya sebagai prediktor. Analisis mediasi menggunakan PROCESS macro untuk SPSS versi 3.2.01 model 6 (Hayes, 2013) dengan 5000 sampel bootstrap pada tingkat kepercayaan 95\%. Analisis mediasi serial digunakan untuk 
memeriksa hubungan langsung antara variabel independen dan dependen mencoblos serta untuk memeriksa hubungan tidak langsung antara variabel efikasi politik ke variabel mencoblos melalui partisipasi daring dan luring.

\section{HASIL DAN PEMBAHASAN}

Hasil analisis regresi mediasi dapat dilihat pada Tabel 1 dan Gambar 1. Analisis regresi mediasi ini secara simultan menganalisis data untuk menjawab hipotesis penelitian.

Hipotesis pertama penelitian ini adalah efikasi politik memprediksi partisipasi politik pemilih pemula dalam memilih pada pemilu 2019. Hasil analisis regresi mediasi menunjukkan bahwa model ke 3 dimana partisipasi memilih menjadi variabel dependen tidak fit dengan data dengan nilai $F(6,399)=$ $0,545, p=0,774$ dan nilai $\mathrm{R}^{2}=0,008$. Efikasi politik tidak secara signifikan memprediksi partisipasi politik memilih dalam pemilu $b=$ $0,110(0,91), t(406)=1,206, p=0,228$. Dengan demikian hipotesis pertama tidak didukung oleh data atau dalam kata lain efikasi politik tidak memprediksi partisipasi politik pemilih pemula dalam memilih pada pemilu 2019.

Hipotesis kedua adalah efikasi politik memprediksi partisipasi politik daring pemilih pemula dalam pemilu 2019. Hasil analisis menunjukkan bahwa efikasi politik secara positif dan signifikan memprediksi partisipasi politik daring $b=0,226(0,036), t(406)=6,245$, $p<0,001$. Efikasi politik beserta covariat, yakni pengetahuan politik dan status sosial ekonomi, menjelaskan $12 \%$ variasi dari partisipasi politik daring $\left(\mathrm{R}^{2}=0,12, F(4,401)=13,697, p<0,001\right)$. Dengan demikian data penelitian mendukung hipotesis kedua atau dalam kata lain efikasi politik memprediksi partisipasi politik daring pemilih pemula dalam pemilu 2019 .

Selanjutnya penelitian ini menguji apakah efikasi politik memprediksi partisipasi luring pemilih pemula dalam pemilu 2019 melalui partisipasi daring mereka. Hasil analisis data secara signifikan mendukung hipotesis ketiga penelitian ini. Efikasi politik tidak signifikan memprediksi partisipasi politk luring secara langsung $(b=0,01(0,022), t(406)=0,463, p$ $=0,641)$. Namun, efikasi politik memprediksi partisipasi politik luring melalui partisipasi politik daring $(b=0,564(0,028), t(406)=$ 19,833, $p<0,001)$. Model prediksi partisipasi politik luring secara signifikan didukung oleh data $\left(F(5,400)=89,580, p<0,001, \mathrm{R}^{2}=0,528\right)$. Variabel efikasi politik, covariat, dan partisipasi politik daring menjelaskan $52,8 \%$ variasi dari partisipasi politik luring. Hasil analisis data untuk hipotesis ketiga mengungkap bahwa efikasi politik memprediksi partisipasi politik daring pemilih pemula yang pada akhirnya akan memprediksi partisipasi politik luring.

Hipotesis terakhir dari penelitian ini adalah efikasi politik memprediksi partisipasi pemilih pemula dalam memilih pada pemilu 2019 melalui partisipasi daring dan partisipasi

Tabel 1 Analisis Regresi Mediasi Serial partisipasi politik

\begin{tabular}{llll}
\hline Variabel & Partisipasi daring & Partisipasi luring & Partisipasi mencoblos \\
\hline Konstan & $0,753(0,197) * * *$ & $0,484(0,114) * * *$ & $3,678(0,491) * * *$ \\
Efikasi politik & $0,226(0,036) * * *$ & $0,010(0,022)$ & $0,110(0,091)$ \\
Pengetahuan politik & $0,014(0,160)$ & $-0,105(0,091)$ & $-0,001(0,384)$ \\
SES (UKT) & $0,046(0,032)$ & $-0,006(0,019)$ & $-0,019(0,078)$ \\
Jenis Kelamin & $-0,135(0,088)$ & $-0,001(0,050)$ & $0,095(0,212)$ \\
Partisipasi daring & - & $0,564(0,028) * * *$ & $-0,228(0,169)$ \\
Partisipasi luring & - & - & $0,113(0,210)$ \\
R2 & $0,120(0,634) * * *$ & $0,528(0,206) * * *$ & $0,008(3,647)$ \\
\hline
\end{tabular}

Sumber: Analisis data penelitian, 2019

*Catatan: Analisis mediasi menggunakan PROCESS macro untuk SPSS versi 3.2.01 model 6 (Hayes, 2013). Semua angka adalah koefisien b tidak terstandarisasi dengan standard error di dalam kurung. Nilai p: $*<0,05 ; * *<0,01 ; * * *<0,001 . \mathrm{n}=406$. Jenis kelamin laki-laki $=0$, perempuan $=1$. 
H1

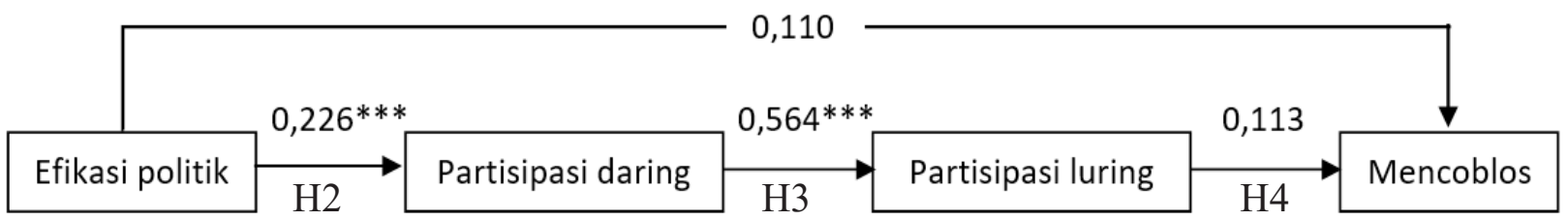

Sumber: Data penelitian, 2019

Gambar 1 Jalur mediasi dari efikasi politik menuju partisipasi politik daring, luring, dan mencoblos

luring mereka secara berurutan. Model prediksi partisipasi memilih pada pemilu 2019 tidak fit atau tidak didukung oleh data $(F(6,399)=0,545$, $\left.p=0,774, \mathrm{R}^{2}=0,008\right)$. Semua variabel hanya menjelaskan $0,8 \%$ variasi dalam partisipasi pemilih pemula memilih. Secara spesifik tidak ada satupun variabel penelitian ini yang secara signifikan memprediksi partisipasi politik memilih pada pemilu. Demikian juga variabel partisipasi politik luring yang dihipotesiskan menjadi mediator dalam memprediksi partisipasi politik memilih ternyata tidak didukung oleh data $(b=0,113(0,210), t$ (406) $=0,535, p=0,593)$. Dengan demikian hipotesis keempat bahwa efikasi politik memprediksi partisipasi pemilih pemula dalam memilih pada pemilu 2019 melalui partisipasi daring dan partisipasi luring mereka secara berurutan tidak didukung oleh data.

Untuk variabel covariat yakni pengetahuan politik, status sosial ekonomi, dan jenis kelamin pemilih pemula ternyata tidak menjadi prediktor yang signifikan dalam ketiga model analisis regresi mediator dalam penelitian ini. Dalam kata lain pengetahuan politik dan status sosial ekonomi tidak memprediksi partisipasi politik pemilih pemula baik secara daring, luring, dan memilih dalam pemilu 2019. Hanya efikasi politik sebagai variabel independen yang secara signifikan memprediksi partisipasi politik pemilih pemula dalam konteks daring yang selanjutnya menghasilkan partisipasi politik luring namun tidak menjelaskan partisipasi memilih dalam pemilu 2019.

Penelitian ini berusaha mengungkap konsep partisipasi politik yang di Indonesia yang lebih fokus pada voting atau memberikan suara pada pemilu dengan dilandasi pada model kesukarelawanan warga (Civic Voluntarism Model/CVM) (Verba et al., 1995). Selain sumber daya atau status sosial ekonomi, model CVM menganggap variabel-variabel sosial-psikologis berperan dalam membentuk partisipasi politik warga negara. Dalam penelitian ini efikasi politik diteorikan menjadi prediktor utama untuk partisipasi politik. Sementara pengetahuan politik dan status sosial ekonomi diteorikan sebagai kontrol atau covariat atau dalam kata lain sebagai prediktor selain prediktor utama.

Sedangkan dalam bentuknya, partisipasi politik diteorikan sebagai sebuah rangkaian dari partisipasi politik yang risikonya paling rendah dan paling mudah dilakukan terutama oleh pemilih pemula yakni partisipasi politik daring. Semakin tinggi dan semakin lancar seorang pemilih pemula melakukan partisipasi politik daringnya akan membentuk partisipasi politik luring sebagai bentuk partisipasi yang lebih berisiko, membutuhkan sumberdaya lebih, dan memiliki dampak yang lebih nyata. Pada akhirnya, bentuk partisipasi nonelectoral ini akan berujung pada partisipasi electoral yakni voting atau memberikan suara pada pemilu. Partisipasi electoral diteorikan sebagai ujung partisipasi bukan karena risiko atau sumber daya yang dibutuhkan, namun lebih pada fokus yang luar biasa diberikan oleh institusi penyelenggara pemilu, elit politik, dan para akademisi di Indonesia. Secara akademis, penelitian ini berusaha menyingkap keterkaitan antara partisipasi politik non-electoral dan electoral berdasarkan model CVM.

Hasil penelitian mengungkap bahwa efikasi politik pemilih pemula memprediksi secara positif dan signifikan partisipasi politik daring. Selanjutnya partisipasi politik daring memprediksi partisipasi politik luring. Namun, partisipasi politik luring dan efikasi politik tidak memprediksi partisipasi politik electoral berupa voting atau memberikan suara pada pemilu 
2019. Lebih lanjut prediktor lainnya seperti pengetahuan politik, status sosial ekonomi, dan jenis kelamin tidak memprediksi partisipasi politik pemilih pemula baik partisipasi politik daring, luring, dan voting.

Model CVM secara parsial di-replikasi dalam penelitian ini, yakni pengaruh efikasi politik terhadap partisipasi daring. Penjenjangan partisipasi politik terkait dengan risiko dan sumber daya yakni dari komunikasi yang bersifat termediasi secara daring dan komunikasi yang lebih langsung dalam konteks luring juga terkonfirmasi dalam penelitian ini, paling tidak dalam konteks partisipasi politik non-electoral.

Namun catatan penting dari penelitian ini adalah bahwa partisipasi electoral dalam bentuk voting tidak diprediksi oleh variabelvariabel di dalam CVM dan partisipasi politik non-electoral. Dalam kajian meta analisis terhadap 90 artikel penelitian ilmiah dari tahun 2000 sampai dengan 2010, Smets dan van Ham (2013) menemukan bahwa dalam model sosial-psikologis dalam menjelaskan partisipasi pemilih (voter turnout) di level mikro, temuan tentang efikasi politik masih belum konklusif. Sebagian besar penelitian mendukung hipotesis bahwa efikasi politik memprediksi partisipasi pemilih, namun secara kategori modalitas lebih banyak penelitian yang gagal mendukung hipotesis tersebut (Smets \& van Ham, 2013). Penelitian ini dengan demikian menambah panjang daftarketidak-konklusifan model efikasi politik terhadap partisipasi pemilih. Terlebih penelitian yang dianalisis oleh Smets dan van Ham adalah penelitian di negara demokrasi maju, sehingga penelitian ini menyumbangkan perspektif tentang model sosial-psikologis dari partisipasi pemilih dari negara demokrasi awal (Smets \& Van Ham, 2013).

Partisipasi pemilih atau voter turnout di tingkatan nasional menurut Cancela dan Geys (2016) justru lebih dipengaruhi oleh variabelvariabel institusional seperti pengeluaran dalam kampanye, kedekatan jarak elektabilitas kandidat dalam poling, dan syarat pendaftaran pemilih. Pemilu 2019 menggabungkan pemilihan presiden dan pemilihan legislatif yang meningkatkan pengeluaran dalam kampanye secara agregat nasional. Kedua, polarisasi politik terutama dalam pemilihan presiden membuat pemilih mempersepsi bahwa elektabilitas antara kedua pasangan calon presiden relatif dekat. Terakhir, pemilih di pemilu 2019 dimudahkan dengan persyaratan bahwa hanya dengan membawa KTP mereka diperbolehkan untuk memilih di luar daerah di mana mereka terdaftar. Bagi mahasiswa rantau, faktor terakhir ini pasti sangat signifikan memprediksi partisipasi mereka dalam memberikan suara di pemilu 2019. Walaupun perlu dibuktikan secara empiris, namun secara teoretis penjelasan tingginya partisipasi pemilih dalam penelitian ini kemungkinan besar lebih dipengaruhi oleh variabel-variabel institusional seperti yang diajukan oleh Cancela dan Geys (2016) dari pada faktor sosial-psikologis dalam model CVM.

Jenjang partisipasi dalam konteks mediasi komunikasi, risiko, dan sumber daya yang dibutuhkan terkonfirmasi dalam penelitian ini namun hanya pada konteks partisipasi politik non-electoral. Namun melihat rerata partisipasi politik daring dan luring mahasiswa Universitas Padjadjaran tentu tidak menggembirakan. Rerata index partisipasi politik daring adalah 1,65 dengan nilai maksimal 7. Sedangkan partisipasi politik luring lebih rendah lagi pada nilai 1,35 dengan nilai maksimal 7. Problem rendahnya partisipasi politik non-electoral justru tidak menjadi fokus institusi penyelenggara pemilu atau elit politik dan bahkan akademisi Indonesia. Perbedaan budaya politik dan bentuk partisipasi antara negara WEIRD dengan Indonesia sebagai negara demokratis yang relatif baru mungkin sangat mempengaruhi rerata nilai yang diperoleh dari pengukuran dengan standar WEIRD. Kebutuhan alat ukur partisipasi politik yang lebih dekat dengan budaya politik Indonesia namun masih bisa dikomunikasikan dan dibandingkan dengan negara WEIRD mutlak dibutuhkan untuk melihat kekhasan namun tidak menghilangkan aspek ilmiah yang sifatnya universal.

Konsekuensi hipotetis dari gambaran yang didapat dari penelitian ini adalah sebuah bentuk pseudo-demokrasi dimana demokrasi dalam pengertian katup komunikasi warga kepada elit hanya dibuka 5 tahun sekali dalam perayaan yang bernama pemilu. Setelah menerima cek kosong dari konstituen di pemilu, saluran komunikasi relatif dibiarkan dalam volume rendah dengan membiarkan partisipasi politik pemilih pemula dalam konteks non-electoral dalam tingkat yang memprihatinkan.

Pasca reformasi, konsolidasi demokrasi 
mulai bekerja di Indonesia, hal ini ditandai dengan tidak hanya bertambahnya jumlah partai yang bertarung di Pemilu, namun juga dengan bertambahnya jumlah pers/jurnalisme yang terbit serta kebebasan warga untuk mengekspresikan suara politiknya bertambah, melalui demonstrasi, kritik langsung dst. Konsolidasi demokrasi dapat didefinisikan sebagai langkah-langkah untuk meningkatkan signifikansi partisipasi politik dengan meminimalkan pentingnya faktor-faktor yang melemahkan partisipasi politik (Nohlen, 2002).

Dengan rendahnya partisipasi politik non-electoral pada pemilih pemula, bahkan di saluran daring, ancaman terhadap konsolidasi demokrasi semakin nyata. Bahkan ketika pelemahan pemberantasan korupsi semakin nyata akhir-akhir ini di Indonesia, mahasiswa sebagai pemilih pemula dan sebagai agen perubahan tidak menunjukkan sikapnya secara tegas dan bermakna. Dari sisi akademis, dibutuhkan kajian dalam penelitian selanjutnya untuk memetakan faktor-faktor yang dapat meningkatkan partisipasi politik non-electoral bahkan dalam bentuknya yang deviant.

Penelitian ini memiliki keterbatasan yakni pertama, populasi penelitian ini bersifat khusus dan tidak bisa digeneralisasikan untuk pemilih pemula seluruh Indonesia. Dibutuhkan studi dalam level provinsi atau nasional untuk mengkonfirmasi hasil penelitian ini terutama terkait jarak antara partisipasi politik nonelectoral dengan electoral. Keterbatasan kedua adalah tidak semua variabel dalam CVM atau prediktor dalam level individual dari partisipasi politik baik electoral maupun non-electoral diperiksa dalam penelitian ini. Penelitian selanjutnya dapat mengikutsertakan variabel prediktor yang lebih komprehensif sehingga dapat lebih menjelaskan variasi dalam partisipasi politik electoral yang gagal dijelaskan oleh penelitian ini. Ketiga, penelitian ini hanya bersifat cross-sectional atau dalam satu waktu, untuk memperolah gambaran tentang peningkatan atau penurunan partisipasi politik pemilih pemula, penelitian selanjutnya dapat menggunakan desain longitudinal menjelang pemilu 2024.

\section{SIMPULAN}

Penelitian ini bertujuan menguji model partisipasi politik dengan efikasi politik sebagai prediktor utama dibantu dengan pengetahuan politik, status sosial ekonomi, dan jenis kelamin. Penelitian ini juga memeriksa penjenjangan partisipasi politik berdasarkan urutan risiko, sumberdaya, dan fokus intervensi yang dilakukan oleh institusi-institusi demokratisasi di Indonesia. Dari hasil analisis data diperoleh simpulan bahwa pertama, efikasi politik tidak memprediksi partisipasi politik pemilih pemula dalam memilih pada pemilu 2019. Kedua, efikasi politik secara positif dan signifikan memprediksi partisipasi politik daring. Ketiga, Efikasi politik tidak signifikan memprediksi partisipasi politk luring secara langsung, namun efikasi politik memprediksi partisipasi politik luring melalui partisipasi politik daring. Keempat. efikasi politik tidak memprediksi partisipasi pemilih pemula dalam memilih pada pemilu 2019 melalui partisipasi daring dan partisipasi luring mereka secara berurutan.

Dari hasil tersebut beberapa rekomendasi telah didiskusikan yakni pertama, secara praktis diperlukan edukasi terhadap pemilih pemula namun tidak terbatas pada partisipasi politik electoral. Kedua, secara akademis dibutuhkan kajian dalam tingkat nasional yang memeriksa faktor-faktor pembangun partisipasi politik baik electoral maupun non-electoral dalam tingkatan individu dan institusional untuk menyusun strategi peningkatan partisipasi politik demi konsolidasi demokrasi di Indonesia. Ketiga, penyusunan alat ukur partisipasi politik yang mengakomodasi kekhasan budaya politik Indonesia namun tetap mempertimbangkan universalitas teori dan bisa dibandingkan dengan penelitian sejenis di seluruh dunia. Keempat, penelitian yang bersifat longitudinal dengan melibatkan pemilih pemula pada pemilu 2024 diperlukan untuk memetakan proses peningkatan atau penurunan partisipasi politik terutama partisipasi politik non-electoral.

\section{DAFTAR PUSTAKA}

Bélanger, E., \& Nadeau, R. (2005). Political trust and the vote in multiparty elections: the Canadian case. European Journal of Political Research, 44(1), 121-146. https:// doi.org/10.1111/j.1475-6765.2005.00221.x

Boulianne, S. (2009). Does internet
use affect engagement? a meta-
$\begin{gathered}\text { analysis of research. } \\ \text { Political }\end{gathered}$


Communication, 26, 193-211. https://doi. org/10.1080/10584600902854363

Boulianne, S. (2015). Social media use and participation: a meta-analysis of current research. Information Communication and Society, 18(5), 524-538. https://doi.org/10. 1080/1369118X.2015.1008542

Boulianne, S. (2018). Twenty Years of Digital Media Effects on Civic and Political Participation. Communication Research. https://doi. org/10.1177/0093650218808186

Cancela, J., \& Geys, B. (2016). Explaining voter turnout: a meta-analysis of national and subnational elections. Electoral Studies, 42, 264-275. https://doi.org/10.1016/j. electstud.2016.03.005

Chadwick, A. (2006). Internet politics: States, citizens, and new communication technologies. New York, NY: Oxford University Press.

Chae, Y., Lee, S., \& Kim, Y. (2018). Metaanalysis of the relationship between Internet use and political participation: Examining main and moderating effects. Asian Journal of Communication, 1-20. https://doi.org/10 $.1080 / 01292986.2018 .1499121$

Dalton, R. J. (2008). Citizen politics: public opinion and political parties in advanced industrial democracies. Washington, D.C: CQ Press.

de Zuniga, H. G., Jung, N., \& Valenzuela, S. (2012). Social media use for news and individuals' social capital, civic engagement and political participation. Journal of Computer-Mediated Communication, 17(3), 319-336. https://doi.org/10.1111/ j.1083-6101.2012.01574.x

Delli Carpini, M. X., \& Keeter, S. (1993). Measuring political knowledge: putting first things first. American Journal of Political Science, 37(4), 1179-1206. DOI: $10.2307 / 2111549$

Djuyandi, Y. (2014). Efektifitas sosialisasi politik pemilihan umum legislatif tahun 2014 oleh komisi pemilihan umum. Humaniora, 5(2), 1202-1212. https://doi. org/10.21512/humaniora.v5i2.3263

Effing, R., Hillegersberg, J. van, \& Huibers, T. W. C. (2011). Social media and political participation: are facebook, twitter and youtube democratizing our political systems? In Electronic Participation: Third IFIP WG 8.5 International Conference, ePart 2011 (hal. 25-35). London: Springer. Farisa, F. C. (2019, Mei). KPU sebut partisipasi pemilih pada pemilu 2019 capai 81 persen. Kompas.com. Diambil dari https://nasional. kompas.com/read/2019/05/27/16415251/ kpu-sebut-partisipasi-pemilih-padapemilu-2019-capai-81-persen

Fincham, J. E. (2008). Response rates and responsiveness for surveys, standards, and the Journal. American Journal of Pharmaceutical Education, 72(2), 43. doi: 10.5688/aj720243

Groves, R. M., \& Peytcheva, E. (2008). The impact of nonresponse rates on nonresponse bias: a meta-analysis. Public Opinion Quarterly, 72(2), 167-189. https://doi. org $/ 10.1093 / \mathrm{poq} / \mathrm{nfn} 011$

Haynes, A. A., \& Pitts, B. (2009). Making an impression: new media in the 2008 presidential nomination campaigns. Political Science \& Politics, 42(1), 53-58.https://doi.org/10.1017/ S1049096509090052

Inglehart, R., \& Norris, P. (2004). Sacred and secular: religion and politics worldwide. Cambridge: Cambridge University Press.

Inglehart, R., \& Welzel, C. (2005). Modernization, cultural change and democracy: The human development sequence. New York, NY: Cambridge University Press.

Jenkins, H., Ito, M., \& Boyd. (2016). Participatory culture in a networked era. Maiden, MA: Polity Press.

KedaiKOPI. (2019). Survei dan FGD: Demonstrasi dan dimensi kepublikan di sekitarnya, periode studi: 28 - 30 September 2019. Diambil dari https://kedaikopi. co/wp-content/uploads/2019/10/Surveidan-FGD-Demonstrasi-dan-DimensiKepublikan-di-Sekitarnya-LembagaSurvei-KedaiKOPI.pdf

Moeller, J., de Vreese, C., Esser, F., \& Kunz, R. (2014). Pathway to political participation: the influence of online and offline news media on internal efficacy and turnout of first-time voters. American Behavioral Scientist, 58(5), 689-700. https://doi. org/10.1177/0002764213515220

Morrell, M. E. (2005). Deliberation, democratic 
decision-making and internal political efficacy. Political Behavior, 27(1), 49-69. DOI 10.1007/s/11109-005-3076-7

Niemi, R. G., Craig, S. C., \& Mattei, F. (1991). Measuring internal political efficacy in the 1988 national election study. The American Political Science Review, 85(4), 14071413. DOI: $10.2307 / 1963953$

Nohlen, D. (2002). Introduction: political participation in new and old democracies. In R. . Pintor \& M. Gratschew (Ed.), Voter Turnout Since 1945: A Global Report. Stockholm: International Institute for Democracy and Electoral Assistance (IDEA) Publications.

Nurhadi, \& Sunarso. (2018). Peran Kiai dalam membangun partisipasi pemilih. Jurnal Ilmiah Pendidikan Pancasila dan Kewarganegaraan, 3(2), 169-175. http:// dx.doi.org/10.17977/um019v3i2p169-175

Putnam, R. (2000). Bowling alone: the collapse and revival of american community. New York: Simon \& Schuster.

Raine, L., \& Smith, A. (2008). The internet and the 2008 election. Washington, dc: pew internet and American life project. Diambil dari http:/www.pewinternet.org/ Reports/2008/The-Internet-andthe-2008Election.aspx

Ramdhani, N. (2008). Sikap dan perilaku: dinamika psikologi mengenai perubahan sikap dan perilaku. Yogyakarta: Universitas Gadjah Mada.

Ro'is, H. (2019, November 1). Dibalik partisipasi pemilih Pemilu 2019. Retrieved September 23, 2020, from https://kab-temanggung. kpu.go.id/wp/dibalik-partisipasi-pemilihpemilu-2019/

Saputri, M. (2019). Kronologi, korban \& efek demo mahasiswa di DPR yang berakhir ricuh. Diambil dari tirto.id website: https:// tirto.id/kronologi-korban-efek-demomahasiswa-di-dpr-yang-berakhir-ricuheiGs

Schlozman, K., L., Verba, S., \& Brady, H. E. (2010). Weapon of the strong? Participatory inequality and the Internet. Perspectives on Politics, 8(2), 487-509. doi:10.1017/ S1537592710001210

Shah, D., Kwak, N., \& Holbert, R. L. (2001). "Connecting" and "disconnecting" with civic life: Patterns of Internet use and the production of social capital. Political Communication, 18, 141-162. https://doi. org/10.1080/105846001750322952

Shah, D., McLeod, J. M., \& Yoon, S. H. (2001). Communication, context, and community: An exploration of print, broadcast, and Internet influences. Communication Research, 28, 464-506. DOI: $10.1177 / 009365001028004005$

Skocpol, T. (2003). Diminished democracy. From membership to management in American civic life. Norman: University of Oklahoma Press.

Skoric, M. M., Zhu, Q., Goh, D., \& Pang, N. (2016). Socialmediaandcitizenengagement: A meta-analytic review. New Media and Society, 18(9), 1817-1839. https://doi. org/10.1177/1461444815616221

Smets, K., \& van Ham, C. (2013). The embarassment of riches? A meta-analysis of individual-level research on voter turnout. Electoral Studies, 32(2), 344-359. https:// doi.org/10.1016/j.electstud.2012.12.006

Stolle, D., \& Micheletti, M. (2013). Political consumerism: global responsibility in action. Cambridge, MA: Cambridge University Press.

Strandberg, K. (2013). A social media revolution or just a case of history repeating itself? The use of social media in the 2011 Finnish parliamentary elections. New Media \& Society, 15, 1329-1347 https://doi. org/10.1177/1461444812470612.

Tenn, S. (2007). The effect of education on voter turnout. Political Analysis, 15(4), 446-464. doi:10.1093/pan/mpm012

The Economist. (2014). Why young people don't vote. Diambil dari The Economist website: https://www.economist.com/ the-economist-explains/2014/10/29/whyyoung-people-dont-vote

Verba, S., Schlozman, K., \& Brady, H. (1995). Voice and equality: civic voluntarism in American politics. Cambridge: Harvard University Press.

Vissers, S., \& Stolle, D. (2014). The Internet and new modes of political participation: online versus offline participation,. Information, Communication \& Society, 17(8), 937-955. https://doi.org/10.1080/13 69118X.2013.867356

Vitak, J, Zube, P., Smock, A., Carr, C. T., Ellison, 
N. B., \& Lampe, C. (2011). It's complicated: FB users' political participation in the 2008 election. Cyberpsychology, Behavior, and Social Networking, 14, 107-1114. https:// doi.org/10.1089/cyber.2009.0226

Vitak, Jessica, \& Ellison, N. B. (2013). 'There's a network out there you might as well tap': exploring the benefits of and barriers to exchanging informational and supportbased resources on Facebook. New Media \& Society, 15(2), 243-259. https://doi. org/10.1177/1461444812451566

Wagunu, A. T. W., Kustiasih, R., Pattisina, E. C., Rinaldi, I., \& Yossihara, A. (2019). Inisiatif membangkitkan partisipasi politik bermunculan. Diambil dari Kompas.id website: https://kompas. $\mathrm{id} / \mathrm{baca} /$ polhuk/2019/04/08/inisiatifmembangkitkan-partisipasi-politikbermunculan/

Ward, S., \& Vedel, T. (2006). Introduction: the potential of the Internet revisited. Parliamentary Affairs, 59(2), 210-225. https://doi.org/10.1093/pa/gs1014

Wardhani, P. S. N. (2018). Partisipasi politik pemilih pemula dalam pemilihan umum.
JUPIIS: Jurnal Pendidikan Ilmu-Ilmu Sosial, 10(1). https://doi.org/10.24114/ jupiis.v10i1.8407.g9060

Xie, B., \& Jaeger, P. . (2008). Older adults and political participation on the internet: a crosscultural comparison of the USA and China. Journal of Cross Cultural Gerontology, 1-15. DOI: 10.1007/s10823007-9050-6

Yamane, T. (1973). Statistics, an introductory analysis (3rd ed.). New York: Harper \& Row.

Yustiningrum, Emilia, R., Ichwanuddin, \& Wawan. (2015). Partisipasi politik dan perilaku memilih pada pemilu 2014. Jurnal Penelitian Politik. Jurnal Penelitian Politik, 12(1), 117-135. https://doi.org/10.14203/ jpp.v12i1.533

Zhang, W., Johnson, T. J., Seltzer, T., \& Bichard, S. L. (2010). The revolution will be networked: the influence of social networking sites on political attitudes and behavior. Social Science Computer Review, 28(1), 75-92. https://doi. org/10.1177/0894439309335162 